\title{
Correction to: Once a quality-food consumer, always a quality-food consumer? Consumption patterns of organic, label rouge, and geographical indications in French scanner data
}

\author{
Mathieu Lambotte ${ }^{1} \cdot$ Stephane De Cara ${ }^{2}$. Valentin Bellassen ${ }^{1}$
}

Accepted: 7 July 2021 / Published online: 6 August 2021

(c) The Author(s) 2021

\section{Correction to: Review of Agricultural, Food and Environmental Studies https://doi.org/10.1007/s41130-020-00,121-z}

The article 'Once a quality-food consumer, always a quality-food consumer? Consumption patterns of organic, label rouge, and geographical indications in French scanner data', written by Mathieu Lambotte, Stephane De Cara and Valentin Bellassen, was originally published Online First without Open Access. After publication in volume 101, issue 1, pages 147-172, the author decided to opt for Open Choice and to make the article an Open Access publication. Therefore, the copyright of the article has been changed to (C) The Authors 2021 and the article is forthwith distributed under the terms of the Creative Commons Attribution.

This article is licensed under a Creative Commons Attribution 4.0 International License, which permits use, sharing, adaptation, distribution and reproduction in any medium or format, as long as you give appropriate credit to the original author(s) and the source, provide a link to the Creative Commons licence and indicate if changes were made. The images or other third-party material in this article are included in the article's Creative Commons licence, unless indicated otherwise in a credit line to the material. If material is not included in the article's Creative Commons licence and your intended use is not permitted by statutory regulation or

The original article can be found online at https://doi.org/10.1007/s41130-020-00121-z.

Mathieu Lambotte

mathieu.lambotte@inrae.fr

1 UMR CESAER, INRA, AgroSup Dijon, Université Bourgogne Franche-Comté, 21000 Dijon, France

2 UMR Economie Publique, INRA, AgroParisTechUniversité Paris-Saclay, 788850 Thiverval-Grignon, France 
exceeds the permitted use, you will need to obtain permission directly from the copyright holder. To view a copy of this licence, visit http://creativecommons.org/licen ses/by/4.0

Publisher's note Springer Nature remains neutral with regard to jurisdictional claims in published maps and institutional affiliations. 